\title{
Grazing impacts on soil nitrogen and phosphorus under Parkland pastures
}

\author{
V.S. BARON*, A.C. DICK, E. MAPFUMO, S.S. MALHI, M.A. NAETH, AND D.S. CHANASYK
}

Research scientist and research associate with Lacombe Research Centre, Agriculture and Agri-Food Canada, 6000 C\&E Trail, Lacombe, Alberta, Canada T4L 1W1; Post-doctoral fellow with the Department of Renewable Resources, University of Alberta, Edmonton, Alberta, Canada T6G 2H1; research scientist with the Melfort Experimental Farm, Agriculture and Agri-Food Canada, Box 1240, Melfort, SK, SOE 1A0; and professors with the Department of Renewable Resources, University of Alberta, Edmonton, Alberta, Canada T6G 2H1. * Corresponding author (Email address: BARONV@EM.AGR.CA).

\section{Abstract}

Because intensive grazing is new to the humid western Canadian parkland (prairies), there is little information available about its effects on soil $N$ and $P$ status. This study addressed the question of grazing intensity and pasture species effects on soil macronutrient status in a Typic Haplustoll at Lacombe, Alberta. Paddocks of smooth bromegrass (Bromus inermis Leyss.), meadow bromegrass (Bromus riparius Rhem.), and winter triticale ( $X$ Triticosecale Wittmack.), replicated 4 times, were subjected to 3 grazing intensities (heavy, medium, and light as defined by frequency and severity of defoliation) using yearling beef heifers. Nitrogen $(\mathbf{N}), \mathbf{P}$ and $\mathrm{K}$ fertilisers were broadcast annually at $\mathbf{1 0 0}$, 22 and $42 \mathrm{~kg} \mathrm{ha}^{-1}$ during production years. The experiment was maintained on the same paddocks for 4 years. In the establishment year and in the third and fourth production years, soil samples were taken randomly from each paddock to a depth of 60 cm. Concentrations of nitrate-N $\left(\mathrm{NO}_{3}-\mathrm{N}\right)$, ammonium-N $\left(\mathrm{NH}_{4}^{-}\right.$ $\mathrm{N}$ ), mineral-N (the sum of $\mathrm{NO}_{3}-\mathrm{N}$ and $\mathrm{NH}_{4}-\mathrm{N}$ ), total Kjeldahl-N, and extractable-P were determined in the $0-15,15-30,30-60$, and 0-60-cm depths. Nitrate-N concentration was (1.7 to 2.4 times) greater for heavy than light grazed treatments for each soil depth increment and the amount of $\mathrm{NO}_{3}-\mathrm{N}$ in the $0-60 \mathrm{~cm}$ depth was 2.2 times greater than light paddocks. More $\mathrm{NO}_{3}-\mathrm{N}$ was measured under perennials than triticale $\left(22.2 \mathrm{vs} 13.6 \mathrm{mg} \mathrm{kg}^{-1}\right.$, respectively) at the 30-60-cm depth. Ammonium-N amount (0-60 cm) was greater in meadow bromegrass $\left(30 \mathrm{~kg} \mathrm{ha}^{-1}\right)$ than in triticale $\left(25 \mathrm{~kg} \mathrm{ha}^{-1}\right)$, but not smooth bromegrass paddocks for the 0 15-cm depth. Extractable-P concentration was greater in the 015-cm depth of heavy $\left(154 \mathrm{mg} \mathrm{kg}^{-1}\right)$ than in medium $\left(138 \mathrm{mg} \mathrm{kg}^{-1}\right)$ or light-grazed $\left(127 \mathrm{mg} \mathrm{kg}^{-1}\right)$ paddocks and was higher under meadow bromegrass than under triticale. Given the large amounts of $\mathrm{NO}_{3}-\mathrm{N}$ in the heavy paddocks, there is potential for loss through both leaching and denitrification. Differences among treatments for $\mathrm{NH}_{4}-\mathrm{N}$, and $\mathrm{P}$ concentrations are not of particular concern environmentally, but are important from a fertility management point of view.

Funding for this research was provided by Canada-Alberta Environmentally Sustainable Agriculture Agreement. Support from Norwest labs, Edmonton, Alberta is greatly appreciated. We thank David Young, Chris Meyers, and Pascal Ogle for technical assistance and Dr. J.R. Robertson and Dr. J. Dormaar for critical review of the manuscript

Contribution No. 939

Manuscript accepted 8 Feb. 01.

\section{Resumen}

Debido a que el apacentamiento intensivo en las praderas húmedas del oeste Canadiense es nuevo hay poca información disponible sobre sus efectos en el estado de $\mathbf{N}$ y $P$ del suelo. Este estudio aborda la interrogante de los efectos de la intensidad del apacentamiento y especie de pradera en el estado de los macronutrientes en un suelo Typic Haplustoll en Lacombe, Alberta. Potreros de "Smooth bromegrass" (Bromus inermis Leyss.), "Meadow bromegrass" (Bromus riparius Rhem.) y "Winter triticale" ( $X$ Triticosecale Wittmack.), repetidos 4 veces, se sometieron a 3 intensidades de apacentamiento (fuerte, media y ligera, definida por la frecuencia y severidad de defoliación) utilizando vaquillas de año de ganado para carne. Anualmente, durante los años de producción, se aplicaron al voleo fertilizantes de Nitrógeno $(\mathrm{N}), \mathrm{P}$ y $\mathrm{K}$ en dosis de 100, 22, and $42 \mathrm{~kg} \mathrm{ha}^{-1}$. El experimento se mantuvo en los mismos potreros durante 4 años. En el año de establecimiento y en el tercer y cuarto año de producción se tomaron en de cada potrero muestras aleatorias de suelo a una profundidad de $60 \mathrm{~cm}$. La concentración de nitratos- $\mathrm{N}\left(\mathrm{NO}_{3}-\mathrm{N}\right)$, amonio- $\mathrm{N}$ $\left(\mathrm{NH}_{4}-\mathrm{N}\right.$ ), $\mathrm{N}$-mineral (la suma de $\mathrm{NO}_{3}-\mathrm{N}$ y $\mathrm{NH}_{4}-\mathrm{N}$ ), N-total Kjeldahl y $P$ extractable se determinó en las profundidades de 0-15, 15-30, 30-60, and 0-60-cm. En cada incremento de profundidad de suelo la concentración de nitratos fue mayor (1.7 a 2.4 veces) en el apacentamiento fuerte que en el apacentamiento ligero y la cantidad de nitratos en la profundidad de $0-60 \mathrm{~cm}$ fue 2.2 veces mayor en los potreros con apacentamiento fuerte. En la profundidad de 30-60 cm se midió más $\mathrm{NO}_{3}-\mathrm{N}$ bajo las especies perennes que bajo el "Triticale" (22.2 vs $13.6 \mathrm{mg} \mathrm{kg}^{-1}$, respectivamente). La cantidad de $\mathrm{N}$-amoniacal $(0-60 \mathrm{~cm})$ fue mayor en las praderas de "Bromegrass" (30 $\left.\mathrm{kg} \mathrm{ha}^{-1}\right)$ que en las "Triticale" (25 $\mathrm{kg} \mathrm{ha}^{-1}$ ), pero no mayor que en los potreros con "Smooth bromegrass" a la profundidad de $0-15-\mathrm{cm}$. La concentración de $P$ extractable en la profundidad de $0-15-\mathrm{cm}$ fue mayor en los potreros con apacentamiento fuerte $\left(154 \mathrm{mg} \mathrm{kg}^{-1}\right)$ que en los potreros con apacentamiento medio $\left(138 \mathrm{mg} \mathrm{kg}^{-1}\right)$ o ligero $(127 \mathrm{mg}$ $\mathrm{kg}^{-1}$ ) y fue mayor bajo la pradera que bajo de "Bromegrass" que bajo el "Triticale". Dadas las grandes cantidades de $\mathrm{NO}_{3}-\mathrm{N}$ en los potreros con apacentamiento fuerte hay potencial para perder $\mathbf{N}$ a través de lixiviación y denitrificación. Diferencias entre tratamientos en las concentraciones de $\mathrm{NH}_{4}-\mathrm{N}$, and $\mathrm{P}$ no son de preocupación ambiental particular, pero son importantes desde un punto de vista de manejo de la fertilidad del suelo.

Key Words: Ammonium, faeces, grazing intensity, macronutrient status, urine 
Intensive rotational grazing is well established in Europe, Australia, and New Zealand, but is still a novel practice on the Canadian prairies. Previous pasture research on the prairie parkland has focused on livestock and herbage responses to applied commercial fertilizer and was carried out at relatively low stocking densities (Doran et al. 1963, Elliot et al. 1961, Kopp et al. 1997). However, Nuttall et al. (1980) found economic returns from mixed alfalfagrass pastures maximized at $90 \mathrm{~kg} \mathrm{~N} \mathrm{ha}^{-1}$ and $20 \mathrm{~kg} \mathrm{P}^{-1}$ when stocking rate was 3.7 head ha-1. In the same study herbage yields increased with $\mathrm{N}$ applications up to $185 \mathrm{~kg}$ $\mathrm{N} \mathrm{ha}^{-1}$, but nitrate-N (NO3-N) accumulated in the $30-60-\mathrm{cm}$ depth of the soil profile. With the exception of the latter study none have reported residual soil macronutrient levels after grazing or studied the effects of varying grazing intensity (frequency and severity) on soil macronutrient status when a moderate level of commercial fertilizer is applied.

It is well known that grazing management affects nutrient cycling and net pools of nutrients in the soil (Haynes and Williams 1993, Whitehead 1995). Intensive pasture management tends to result in swards of relatively high nutritive value (Wedin 1996), which influences the nature and bioavailability of excreta (Haynes and Williams 1993, Mathews et al. 1996, Whitehead 1995). Nutrient cycling and pools of mineralized nutrients in soil are products of complex relationships among chemical, physical, and biological characteristics of the soil, sward composition, livestock species, type, and management, and climate (Haynes and Williams 1993). The processes involved are similar by geo-climatic region, but the net effects of nutrient cycling may vary from region to region. Grazing intensity regulates residual leaf area which influences pasture growth rate and therefore nutrient uptake (Briske and Heitschmidt 1991). In a short season area such as the parkland, early season pasture yields of perennial grasses are high relative to the late season, when cool temperatures and dry weather may slow or curtail growth. Efficient utilization of pastures through intensive grazing during the early season may cause a build-up of mineralized soil nutrients during the late summer and fall when plant growth and nutrient uptake is slow.

Different pasture species affect nutrient use and turnover due to seasonal timing of growth (Stout et al. 1997), root type, depth, carbon to nitrogen $(\mathrm{C}: \mathrm{N})$ ratio, and legume versus non-legume species composition (Wedin and Tilman 1990, Wedin 1996). Cool season grasses are widely used in pastures on the prairie parkland and when grown in rotational sequences with cereal and oil-seed crops, the average life of a stand is 5 years (Entz et al. 1995). Breaking or cultivation of forage stands to place them in annual-crop rotations results in the mineralization of large amounts of $\mathrm{N}$. Residual effects of this $\mathrm{N}$ on succeeding cereal crops have been demonstrated for up to 7 years (Hoyt and Leitch 1983). Pasturing annual species, such as Italian ryegrass (Lolium multiflorum Lam.) and spring-planted winter cereals (Baron et al. 1993) is of interest because of increased flexibility in land-use options on a year-toyear basis.

Concerns for ground water contamination from $\mathrm{NO}_{3}-\mathrm{N}$ (mostly related to manure application) arise when late-fall $\mathrm{NO}_{3}-\mathrm{N}$ accumulations exceed $160 \mathrm{~kg} \mathrm{ha}^{-1}$ in the upper $1.2 \mathrm{~m}$ of soil (Ewanek 1995). Similarly, losses of P by overland flow during snowmelt are a concern when extractable $\mathrm{P}$ levels exceed $330 \mathrm{~kg} \mathrm{ha}^{-1}$ in the upper $20-\mathrm{cm}$ of soil (Johnson and Eckert 1995). A knowledge of the relationship of late season accumulations of soil nutrients to grazing intensity may provide insights for improved grazing management, which could be both economically and environmentally prudent. The objective of this study was to determine the effect of grazing intensity and pasture grass species on late-season concentrations of mineralized-N and extractable-P over a 4-year period beginning with the establishment year of the perennial grasses.

\section{Materials and methods}

\section{Experiment establishment and pad- dock management}

A study was established in 1993 at the Lacombe Research Centre $\left(52^{\circ} 28^{\prime} \mathrm{N}\right.$; $113^{\circ} 45^{\prime} \mathrm{W} ; 847 \mathrm{~m}$ ) on a Penhold silt loam (coarse-loamy, mixed, frigid, Typic Haplustoll) soil. Complete details of the experimental layout have been published previously (Mapfumo et al. 2000). Historically, the site was a 15 -year-old extensively managed (low input) perennial grass pasture composed of smooth bromegrass (Bromus inermis Leyss.), quackgrass (Elytrigia repens L.), and Kentucky bluegrass (Poa pratensis L.). Cultivation of the site commenced in the summer of 1992 so that new species could be established in 1993. The first production year was 1994. Originally, 4 forage species treatments were established (Mapfumo et al. 2000); however, only 3 were continued until 1997. These were 'Carlton' smooth bromegrass, 'Paddock' meadow bromegrass (Bromus riparius Rhem.) and 'Pika' winter triticale ( $X$ Triticosecale Wittmack.). These 3 species treatments were combined in a factorial arrangement with 3 levels of grazing intensity ( 9 paddocks per replication). Treatments were laid out in $9 \mathrm{~m} \times 33 \mathrm{~m}$ paddocks in a randomized complete block design with 4 replicates.

Perennial grasses were seeded in the spring of 1993. Winter triticale paddocks were seeded annually, after cultivation, beginning in the spring of 1993. Prior to seeding all treatments in 1993, the experimental area received a broadcast application of $8,14,26$, and $5 \mathrm{~kg}$ ha- 1 of $\mathrm{N}, \mathrm{P}, \mathrm{K}$, and $\mathrm{S}$, respectively, followed by a light cultivation and packing. Smooth bromegrass and meadow bromegrass were broadcast-seeded at a rate of 11.2 and 16.8 $\mathrm{kg} \mathrm{ha}^{-1}$ respectively, mixed with $1 \mathrm{~kg} \mathrm{ha}^{-1}$ of 'Spredor II' alfalfa (Medicago sativa L.). Triticale was seeded at $135 \mathrm{~kg} \mathrm{ha}^{-1}$ with 2 passes of a plot seeder (packer wheels in front, double disk openers at 25$\mathrm{cm}$ row spacing and packer wheels behind) at an effective row spacing of 12.5 $\mathrm{cm}$. All seeding was followed immediately by harrowing and packing. All plots were hand weeded after establishment and were grazed 3 times in the fall of 1993. No tillage was done before winter on triticale plots. By the time of the current study in 1996 and 1997, there was almost no alfalfa remaining in the perennial paddocks. Each spring (1994 to 1997, inclusive) fertilizers to supply 100,22 , and $42 \mathrm{~kg} \mathrm{ha}^{-1}$ of $\mathrm{N}, \mathrm{P}$, and $\mathrm{K}$, respectively were broadcast over the experimental area. Triticale plots were rototilled and seeded as described above. The herbicide MCPA [(4-chloro-2methylphenoxy) acetic acid] was applied (600 g active ingredient (a.i.) ha ${ }^{-1}$ in 1994 to 1996 , and $900 \mathrm{~g}$ a.i. ha ${ }^{-1}$ in 1997 ) to the triticale plots to control weeds. No herbicide was applied in perennial grass plots.

\section{Grazing treatments}

Each paddock was fenced with wooden posts and high-tensile smooth wire that was electrified to contain cattle and prevent grazing of adjacent plots. From 1994 to 1997 , paddocks were grazed rotationally by yearling heifers, with 3 grazing intensities (represented by different pregrazing canopy heights) superimposed on each crop species. Canopy heights for grazing initiation were determined using the weighted disk method (Bransby et al. 1977). Target pre-grazing heights for perennial forages averaged 13, 17, and 26 $\mathrm{cm}$ for heavy, medium, and light grazing, respectively. Target heights for triticale 
Table 1. Summary of grazing treatments averaged over 1996 and 1997 at Lacombe, Alberta.

\begin{tabular}{|c|c|c|c|c|c|}
\hline $\begin{array}{l}\text { Crop and grazing } \\
\text { intensity }\end{array}$ & $\begin{array}{l}\text { Date of } \\
\text { initial } \\
\text { grazing }^{1}\end{array}$ & $\begin{array}{l}\text { Number of } \\
\text { grazing }\end{array}$ & $\begin{array}{c}\text { Mean rest } \\
\text { period }\end{array}$ & $\begin{array}{c}\text { Total } \\
\text { animal } \\
\text { days }\end{array}$ & Stocking rate \\
\hline & & (Days) & & & $\left(\right.$ AUM. ha $\left.{ }^{-1}\right)$ \\
\hline \multicolumn{6}{|c|}{ Smooth bromegrass } \\
\hline Heavy & 29 May & 6 & 22 & 29.5 & 26.5 \\
\hline Medium & 3 June & 4 & 24 & 18.9 & 17.0 \\
\hline Light & 10 June & 3 & 50 & 14.2 & 12.7 \\
\hline \multicolumn{6}{|c|}{ Meadow bromegrass } \\
\hline Heavy & 29 May & 5 & 22 & 23.5 & 21.1 \\
\hline Medium & 4 June & 3.5 & 23 & 14.3 & 12.8 \\
\hline Light & 11 June & 3 & 56 & 13.9 & 12.5 \\
\hline \multicolumn{6}{|l|}{ Triticale } \\
\hline Heavy & 10 July & 3.4 & 18 & 15.5 & 13.9 \\
\hline Medium & 14 July & 3 & 34 & 9.4 & 8.4 \\
\hline Light & 29 July & 2 & 49 & 5.7 & 5.1 \\
\hline
\end{tabular}

Date of first grazing varied for the 2 years. The date given is the mid-point between the 2 actual dates.

were 11,12 , and $21 \mathrm{~cm}$ for heavy, medium and light grazing respectively. These heights were used to maintain consistency, not to predict pasture yield. Approximately 84,73 , and $64 \%$ of annual production disappeared from heavy, medium and light grazing, respectively. Forage species and grazing parameters are given in Table 1. From 2 to 6 heifers were placed in a paddock at one time. Grazing time was measured in hours and calculated as animal days per paddock. Each grazing event was less than 24 hours.

\section{Soil sampling}

In addition to the soil sampling described by Mapfumo et al. (2000), samples were taken to monitor soil mineral-N and extractable $\mathrm{P}$ concentrations. Soil cores were taken from 3 random locations in each paddock (i.e. all grazing intensity $\times$ species $\times$ replicate combinations). Soil samples were taken in October of 1993 (establishment year), 1994, 1995, 1996, and 1997 to a depth of $60 \mathrm{~cm}$ using a hydraulically powered sampler with a 5.1$\mathrm{cm}$ diameter probe. Soil cores were sliced into depth segments of $0-15,15-30$ and $30-60 \mathrm{~cm}$ and bulked by depth.

In 1993, samples were bulked over replicates and grazing intensities, as the grazing intensity treatments were not initiated until 1994. In 1994 and 1995 samples were bulked over replicate, but not grazing intensity levels. In 1994 and 1995 soils were analysed for soil $\mathrm{NO}_{3}-\mathrm{N}$ and extractable-P (data not shown). Because of trends observed for soil $\mathrm{NO}_{3}-\mathrm{N}$ concentration with increasing grazing intensity in 1994 and 1995, more complete soil analyses were conducted for 1996 and 1997 data. Data for 1993 were used to deter- mine differences for soil mineral-N, and extractable-P concentrations between the fall of the establishment year and the fall of 1996 and 1997. The data (means) from 1993 were the same for all grazing intensities and replicates. The data for 1996 and 1997 were used to determine sequential year effects of treatments after 3 and 4 years of grazing, respectively.

All samples were transported from the field immediately, spread in shallow pans, and dried at room temperature in a forcedair dryer. Following drying, the samples were ground to pass a $2-\mathrm{mm}$ screen (Custom Laboratory Equipment Inc, Orange City, Fla). In October of 1996 and 1997, concentrations of $\mathrm{NH}_{4}-\mathrm{N}(\mathrm{KCl}$ extracted), $\mathrm{NO}_{3}-\mathrm{N}\left(\mathrm{CaCl}_{2}\right.$ extracted $)$, total Kjeldahl-N, and extractable P ("modified Kelowna" extract; Ashworth and Mrazek 1995) were determined using a Technicon autoanalyzer with industrial methods 79186T, 782-86T, 786-86T, and 792-86T, respectively (Technicon Industrial Systems Corp., Tarrytown, N.Y). Pool sizes of nutrients for respective depths were calculated by converting concentrations to quantities $\left(\mathrm{kg} \mathrm{ha}^{-1}\right)$ using bulk density determinations for each paddock. Bulk densities were determined using a Campbell Pacific Nuclear density/moisture probe. Three aluminium access tubes were installed in each paddock. Measurements were taken by lowering the probe down the access tube. Readings were taken at $15-\mathrm{cm}$ depth and thereafter at increments of $10 \mathrm{~cm}$. At each depth 2 readings were taken and used to calculate the average value for that depth. The calibration equation for the probe was used to calculate bulk density for the depth used and the standard count reflecting prevailing environmental conditions.

\section{Statistical analysis}

Initial data from 1993 were not analysed statistically within years, as replicates were not included. The following refers to the difference in $\mathrm{NO}_{3}-\mathrm{N}$ and extractable $\mathrm{P}$ concentrations between 1993 and 1996 and 1997 as well as $\mathrm{NH}_{4}-\mathrm{N}, \mathrm{NO}_{3}-\mathrm{N}$, mineral- $\mathrm{N}$ and extractable-P concentrations for 1996 and 1997. Data were subjected to analysis of variance using the SAS GLM procedure (SAS 1989) with a split-plot model. Grazing levels (GL) and species (S) were main plot effects tested for significance using replicates $(r e p) \times \mathrm{GL} \times \mathrm{S}$ as the error term, years (repeated measures) were a subplot tested with rep $\times$ year error term, and the interactions were tested with the residual error (Steel and Torrie 1980). Where the F-test indicated a significant $(\mathrm{P}<0.05)$ effect, means were separated by calculation of least significant differences (LSD) using the appropriate error mean squares. Single-degree of freedom comparisons (contrasts) were also used to determine differences between the perennial grasses and triticale.

\section{Results and Discussion}

\section{Post establishment soil nutrient con- centrations}

Soil nutrient concentrations were determined the year after cultivation of a longterm grass stand, in the fall of the establishment year, after a season of growth for the perennials and before grazing treatments had been imposed. The first nutrient concentration values (Table 2) included no variability for replicates, so only qualitative observations are valid. Nitrate-N $\left(\mathrm{NO}_{3}-\mathrm{N}\right)$ concentrations were high in the 0-6-cm depth under all species but were numerically 2 to 5 times higher under perennials than triticale at 15-30- and 30-60-cm depths. The extractable-P concentration for triticale was reduced slightly relative to the perennials at the $0-15-\mathrm{cm}$ depth. During the establishment year yield for species was not assessed, but visually the perennial stands were representative of seedling forage stands with dry matter production lower than triticale. Thus, a higher uptake of nutrients by the triticale compared to perennials could be expected.

Ferguson and Gorby (1971) observed that soil $\mathrm{NO}_{3}-\mathrm{N}$ pools on a similar soil, 1 year after cultivation of a grassland ranged from 90 to $135 \mathrm{~kg} \mathrm{ha}^{-1}(0-60 \mathrm{~cm})$ compared to $35 \mathrm{~kg} \mathrm{ha}^{-1}$ after a grain-grain fallow rotation when planted to wheat. Mineralization may release up to $200 \mathrm{~kg} \mathrm{~N}$ $\mathrm{ha}^{-1}$ when grasslands are cultivated 
Table 2. Concentrations of soil $\mathrm{NO}_{3}-\mathrm{N}$ and extractable-P in $0-15,15-30$, and 30-60-cm depths determined in the fall of the establishment year (1993) prior to imposition of grazing treatments at Lacombe, Alberta.

\begin{tabular}{lcc}
\hline \hline Species & \multicolumn{2}{c}{$\begin{array}{c}\text { Soil nutrient concentration } \\
\text { Extractable-P }\end{array}$} \\
\hline & $\mathrm{NO}_{3} \mathrm{~N}$ & 144 \\
\hline$-15 \mathrm{~cm}$ & & 147 \\
Smooth bromegrass & 40 & 118 \\
Meadow bromegrass & 36 & 136 \\
Triticale & 33 & \\
Mean & 36 & 41 \\
15-30 cm & & 39 \\
Smooth bromegrass & 40 & 33 \\
Meadow bromegrass & 33 & 38 \\
Triticale & 8 & \\
Mean & 27 & 14 \\
30-60-cm & & 21 \\
Smooth bromegrass & 32 & 15 \\
Meadow bromegrass & 28 & 17 \\
Triticale & 10 & \\
Mean & 23 & \\
\hline
\end{tabular}

(Whitehead 1995). Carry over effects $\left(\mathrm{NO}_{3}-\mathrm{N}\right)$ of grassland cultivation lasted approximately 2 years in the study of Ferguson and Gorby (1971).

\section{Changes in soil nutrient concentra- tions over time.}

Species effects were minimal and grazing intensity effects weren't significant in all depths for change in nutrient concentrations from 1993 to 1997 suggesting that changes over time were relatively similar among treatments. However, changes did occur. Nitrate $\left(\mathrm{NO}_{3}-\mathrm{N}\right)$ concentration decreased under smooth bromegrass and increased slightly under triticale in the $15-30-\mathrm{cm}$ depth and extractable-P concentration decreased more under meadow bromegrass than under smooth bromegrass or triticale in the 30-60-cm depth (Table 3).

Soil mineral-N status measured in the fall reflects the net supply as a result of pasture uptake, mineralization of organic matter, addition of fertilizer-nutrients, cycling of nutrients through cattle, as well as immobilization and losses (leaching and denitrification). Mapfumo et al. (2000) showed significant increases in total Kjeldahl-N concentration for the $0-5$ and

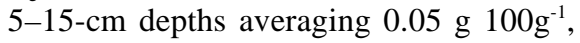
indicating $\mathrm{N}$-loss from the system may have been minimal. The extent of N-loss has not been determined under grassland

Table 3. Effect of forage species on changes in concentrations of soil $\mathrm{NO}_{3}-\mathrm{N}$, and extractable-P in 0-15, 15-30, and 30-60-cm depths, sampled in the fall after 4 years (1993 to 1997) of grazing at Lacombe, Alberta.

\begin{tabular}{lcc}
\hline \hline & \multicolumn{2}{c}{ Change in concentration } \\
Species & $\mathrm{NO}_{3}-\mathrm{N}$ & Extractable-P \\
\hline & & \\
$0-15 \mathrm{~cm}$ & -24.6 & 10.6 \\
Smooth bromegrass & -13.2 & -11.3 \\
Meadow bromegrass & -19.0 & 10.0 \\
Triticale & -18.8 & 2.9 \\
Mean & $\mathrm{ns}$ & $\mathrm{ns}$ \\
LSD 0.05 & \multicolumn{2}{c}{} \\
15-30 cm & -15.7 & 6.4 \\
Smooth bromegrass & -6.6 & 0.0 \\
Meadow bromegrass & 8.6 & -2.0 \\
Triticale & -4.3 & 1.3 \\
Mean & 21.4 & $\mathrm{~ns}$ \\
LSD 0.05 & & \\
$30-60 \mathrm{~cm}$ & -8.4 & -3.4 \\
Smooth bromegrass & -4.8 & -10.2 \\
Meadow bromegrass & 2.6 & -4.8 \\
Triticale & -3.4 & -6.2 \\
Mean & $\mathrm{ns}$ & 4.7 \\
LSD 0.05 & & \\
\hline
\end{tabular}

ns not significant $(\mathrm{P}<0.05)$.

in this geo-climatic area. However, the complexity involved and dynamics of exchanges between mineral and organic- $\mathrm{N}$ are large in a grazing system and explanation of possible N-loss from the system is beyond the scope of this study.

Post establishment soil $\mathrm{NO}_{3}-\mathrm{N}(15-30-\mathrm{cm})$ values were high for both perennials and low for triticale (Table 2). Growth of triticale lags about 6 weeks behind bromegrass in the spring. Over this period soil $\mathrm{NO}_{3}-\mathrm{N}$ could be leached downward in the soil profile for triticale. The net effect could have been a large decrease, due to plant uptake, for the perennial and a slight increase for the annual.

Extractable-P changed marginally over 4 years, increasing on average $2.9 \mathrm{mg} \mathrm{kg}^{-1}$ in the $0-15-\mathrm{cm}$ depth. Changes in extractable-P concentration in the soil profile seem to indicate plant uptake from the 30-60-cm depth, with subsequent cycling through the grazing animals and deposition on the surface. Because root weight of meadow bromegrass was 3 times that of triticale and $110 \%$ of smooth bromegrass in the $30-60-\mathrm{cm}$ soil layer (Baron et al. 1999) it may have been more effective in cycling $\mathrm{P}$.

\section{Soil nutrient concentration after 4 years of grazing}

Heavy grazing resulted in higher $\mathrm{NO}_{3}-\mathrm{N}$ and mineral- $\mathrm{N}$ concentrations in the $0-15$ $\mathrm{cm}$ and $15-30-\mathrm{cm}$ depths and greater amounts of $\mathrm{NO}_{3}-\mathrm{N}$ and mineral-N in the 0-60 cm depth than light grazing (Tables 4 and 5). The medium grazing intensity was intermediate for $\mathrm{NO}_{3}-\mathrm{N}$ and mineral-N concentrations at all depths, but was not significantly different from the other grazing intensities at the $0-15-\mathrm{cm}, 15-30-\mathrm{cm}$ and $30-60-\mathrm{cm}$ depths. However, heavy grazing had greater amounts of $\mathrm{NO}_{3}-\mathrm{N}$ than the other grazing intensities (including medium) in the $0-60-\mathrm{cm}$ depth (Table 5). Year did not interact significantly $(\mathrm{P}>0.05)$ with the other factors and grazing intensity did not interact significantly with species.

The positive relationship between grazing intensity and soil NO3-N concentration is consistent with observations of others (Haynes and Williams 1993, Whitehead 1995). While grazing intensities used in the heavy grazing treatment may be greater than used in practice, a concurrent study (Baron et al. 1999) indicated that the heavy grazing intensity resulted in $20 \%$ more dry matter disappearance, with only an $8 \%$ reduction in above ground net productivity compared to light grazing. In addition, herbage- $\mathrm{N}$ content positively affects $\mathrm{N}$ concentration of urine and the proportion of total-N excreted in urine (Haynes and Williams 1993, Whitehead 1995, Stout et 
Table 4. Mean concentrations of $\mathrm{NO}_{3}-\mathrm{N}, \mathrm{NH}_{4}-\mathrm{N}$, and mineral-N in $0-15,15-30$ and 30-60-cm soil depths sampled in the fall after third and fourth years (1996 and 1997) of rotational grazing at 3 grazing intensities at Lacombe, Alberta.

\begin{tabular}{|c|c|c|c|}
\hline Parameters & $\mathrm{NO}_{3}-\mathrm{N}$ & $\mathrm{NH}_{4}-\mathrm{N}$ & Mineral-N \\
\hline $\begin{array}{l}\text { Grazing intensity } \\
0-15 \mathrm{~cm}\end{array}$ & \multicolumn{3}{|c|}{ 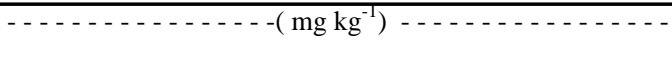 } \\
\hline$\overline{\text { Heavy }}$ & 44.3 & 9.3 & 53.6 \\
\hline Medium & 28.2 & 8.1 & 36.3 \\
\hline Light & 25.5 & 8.9 & 34.4 \\
\hline Mean & 32.7 & 8.8 & 41.5 \\
\hline $\mathrm{LSD}_{0.05}$ & 16.8 & $\mathrm{~ns}^{1}$ & 18.0 \\
\hline \multicolumn{4}{|l|}{$15-30 \mathrm{~cm}$} \\
\hline Heavy & 41.2 & 3.2 & 44.4 \\
\hline Medium & 21.8 & 4.0 & 25.9 \\
\hline Light & 17.4 & 3.8 & 21.2 \\
\hline Mean & 26.9 & 3.7 & 30.6 \\
\hline $\mathrm{LSD}_{0.05}$ & 22.7 & $\mathrm{~ns}$ & 23.0 \\
\hline \multicolumn{4}{|l|}{$\underline{30-60 \mathrm{~cm}}$} \\
\hline Heavy & 27.9 & 3.0 & 30.7 \\
\hline Medium & 14.0 & 3.0 & 17.0 \\
\hline Light & 15.8 & 3.1 & 18.9 \\
\hline Mean & 19.3 & 3.0 & 22.3 \\
\hline $\mathrm{LSD}_{0.05}$ & ns & ns & ns \\
\hline
\end{tabular}

1ns not significant $(\mathrm{P}>0.05)$. Reasons for more $\mathrm{NH}_{4}-\mathrm{N}$ under meadow al. 1997). The mean herbage-N concentration $(2$ yr $\times 3$ species $)$ immediately prior to grazing was $34.4 \mathrm{~g} \mathrm{~kg}^{-1}$ and $27.9 \mathrm{~g} \mathrm{~kg}^{-1}$ for heavy and light grazing intensities, respectively (Baron et al. 1999). This is indicative of a greater nutrient turnover on heavy compared to light and medium grazing intensities. More $\mathrm{N}$ in urine form was deposited on heavy compared to light grazed treatments. Based solely on grazing time and animal density, estimated urine and faeces loading data indicate that the heavy grazing treatment was exposed to 2.4 times more excreta than the light grazing (Table 6). Thus, input sources of mineralized-N to the heavy grazed system had to be greater than the others; additions of fertilizer- $\mathrm{N}$ were similar for all treatments. On the well-drained site of the present

study, nitrification of urine would be rapid and denitrification minimal so one would expect to find most of the mineral- $\mathrm{N}$ in the $\mathrm{NO}_{3}$ form rather than the $\mathrm{NH}_{4}$ form, which was confirmed by the data (Table 5).

Ammonium-N concentration was not significantly affected by grazing intensity or species for any of the depths, but the amount of ammonium in the $0-60 \mathrm{~cm}$ depth under meadow bromegrass was higher than under triticale (Table 5). bromegrass than triticale are obscure, however the difference between the two species was small. The difference between the species for $\mathrm{NH}_{4}-\mathrm{N}$ amounts is not as simple as perennial vs. annual, because smooth bromegrass and triticale had similar amounts of soil $\mathrm{NH}_{4}-\mathrm{N}$. It is possible

Table 5. Mean amounts of $\mathrm{NO}_{3}-\mathrm{N}, \mathrm{NH}_{4}-\mathrm{N}$, and mineral-N in 0-60-cm soil depth sampled in the fall after third and fourth years (1996 and 1997) of rotational grazing of annual and perennial grass species at 3 grazing intensities at Lacombe, Alberta.

\begin{tabular}{lccc}
\hline \hline Parameters & $\mathrm{NO}_{3}-\mathrm{N}$ & $\mathrm{NH}_{4}-\mathrm{N}$ & Mineral-N \\
\hline Grazing intensity & 213 & 27.4 & 240 \\
\hline Heavy & 138 & 26.7 & 164 \\
Medium & 95 & 29.5 & 133 \\
Light & 148 & 27.8 & 179 \\
Mean & 74 & $\mathrm{~ns}$ & 76 \\
LSD 0.05 & & & \\
Species & 173 & 28.2 & 201 \\
Smooth bromegrass & 152 & 30.2 & 182 \\
Meadow bromegrass & $162^{*}$ & 29.2 & $192^{*}$ \\
Perennial mean & $122^{*}$ & 25.1 & 175 \\
Triticale & 147 & 27.8 & $\mathrm{~ns}$ \\
Overall mean & ns & 3.6 & \\
LSD 0.05 & & & \\
1 ns not significant $(\mathrm{P}>0.05)$ & &
\end{tabular}

that nitrification of $\mathrm{NH}_{4}-\mathrm{N}$ was reduced under meadow bromegrass compared to triticale and smooth bromegrass. Wedin and Tilman (1990) observed differences among species and reviewed literature, confirming variability among species for reduced nitrification. However, the higher $\mathrm{NH}_{4}-\mathrm{N}$ for meadow bromegrass should have been accompanied by lower soil $\mathrm{NO}_{3}-\mathrm{N}$, but this was not the case (Table $5)$. On the contrary there was a trend for more $\mathrm{NO}_{3}-\mathrm{N}$ for both perennials than triticale in the $0-60-\mathrm{cm}$ soil depth.

The species effect was not significant for $\mathrm{NO}_{3}-\mathrm{N}$ or mineral-N concentration for any depth. However, single-degree of freedom contrasts indicated $\mathrm{NO}_{3}-\mathrm{N}$ and mineral- $\mathrm{N}$ concentrations under the perennial grasses (22.2 and $25.2 \mathrm{mg} \mathrm{kg}^{-1}$, respectively) were greater than those under triticale (13.6 and $16.5 \mathrm{mg} \mathrm{kg}^{-1}$, respectively) in the $30-60-\mathrm{cm}$ depth. Amounts of NO3-N and mineral- $\mathrm{N}$ in the $0-60-\mathrm{cm}$ depth (Table 5) were greater under the perennial grasses than under triticale. This was likely due to a greater turnover of nitrogenous material by cattle. Annual aboveground net productivity for perennials averaged $130 \%$ of triticale (Baron et al 1999). While this should have positively influenced uptake of mineralized-N, it also resulted in more grazing days (Table 1). Estimated urine volume and faeces mass on the perennial paddocks was twice that of triticale (Table 6).

Amounts of $\mathrm{NO}_{3}-\mathrm{N}(0-60-\mathrm{cm})$ were higher in the present study than reported for other cropping systems used in the same region. Approximate residual $\mathrm{NO}_{3}-$ $\mathrm{N}$ levels taken in the fall under barley stubble and summerfallow (Malhi and Nyborg 1986) were $25 \%$ and $65 \%$, respectively of those found under light grazing (Table 5) with similar soils and fertilizer$\mathrm{N}$ applied to the barley. Also, amounts of $\mathrm{NO}_{3}-\mathrm{N}$ reported here were substantially higher than observed for extensively managed long term grasslands (Woodmansee et al. 1981). In long-term grasslands mineralization may be limited by low available soil moisture (Campbell et al. 1990), immobilization due to high organic residues and root masses (Woodmansee et al. 1981, Whitehead 1995, Wedin 1996) and large microbial biomasses. In a concurrent study using the same treatments surface soil moisture occasionally reached field capacity due to rainfall each summer (Twerdoff et al. 1999). Thus, low soil moisture did not likely limit mineralization of organic reserves over long periods and immobilization may not have been as large a factor as in extensively managed grasslands. 
Table 6. Estimated urine and faeces loading ${ }^{1}$ on rotationally grazed annual and perennial grass pastures with 3 grazing intensities at Lacombe, Alberta.

\begin{tabular}{lcc}
\hline \hline Parameters & Urine volume & Faeces mass \\
\hline Species & $\left(\right.$ litre $\left.\mathrm{ha}^{-1} \mathrm{yr}^{-1}\right)$ & $\left(\mathrm{kg} \mathrm{DM} \mathrm{ha}^{-1} \mathrm{yr}^{-1}\right)$ \\
Smooth bromegrass & 16852 & 1348 \\
Meadow bromegrass & 15720 & 1258 \\
Triticale & 8559 & 685 \\
Grazing intensity & & \\
Heavy & 18615 & 1489 \\
Medium & 10075 & 806 \\
Light & 7919 & 634 \\
\hline
\end{tabular}

${ }^{1}$ Based on average number of cow-days of grazing on each treatment over a 4-yr period and average daily volumes and masses of excreta for steers on pasture according to Whitehead (1993).

The levels of $\mathrm{NO}_{3}-\mathrm{N}$ found in the medium and heavy grazing treatments may be high enough to be of environmental concern. Ewanek (1995), in Manitoba, suggested a threshold of $160 \mathrm{~kg} \mathrm{ha}^{-1}$ in the top $1.2 \mathrm{~m}$ of soil as a level above which leaching might occur. Nitrate- $\mathrm{N}$ levels under heavy grazing exceeded $160 \mathrm{~kg} \mathrm{ha}^{-1}$ in the upper $60 \mathrm{~cm}$.

Extractable-P concentrations in the 0$15-\mathrm{cm}$ soil depth under heavy grazing, averaged across years and species, were higher than under medium or light grazing (154, 138, and $127 \mathrm{mg} \mathrm{kg}^{-1}$, respectively, LSD = 24). Roquette et al. (1973) found available soil-P increased by a factor of 3 after grazing coastal bermudagrass at 4.7 animal units $\mathrm{ha}^{-1}$ for 2 years. Differences in $\mathrm{P}$ levels among grazing intensities in the present study generally reflected levels of estimated excreta (Table 6). Phosphorus is excreted only in faeces and is not mobile (Haynes and Williams 1993). Therefore, higher $\mathrm{P}$ concentrations might be expected in a shallower depth (i.e., $0-5 \mathrm{~cm}$ ), than in the $0-15 \mathrm{~cm}$ layer sampled. Differences among species for $\mathrm{P}$ level were related to differences in animal grazing days between perennials and triticale.

\section{Summary}

Change of soil mineral-N and extractable-P concentration from establishment year until third and fourth production years were not related to grazing intensity. Total losses of soil NO3-N may have been minimal after cultivation and reestablishment since Mapfumo et al (2000) observed a net gain in total-N on surface soils in a related study. The changes observed for extractable-P indicated cycling from the $30-60-\mathrm{cm}$ soil depth to the surface by meadow bromegrass more than the other species.

During the third and fourth year after grazing was initiated, grazing intensity strongly influenced soil $\mathrm{NO}_{3}-\mathrm{N}$ levels down to the $60-\mathrm{cm}$ soil depth across all species. Soil $\mathrm{NO}_{3}-\mathrm{N}$ concentrations for heavy grazed treatments were 1.7-2.4 times greater than light grazed treatments. Amounts of residual soil $\mathrm{NO}_{3}-\mathrm{N}$ and mineral-N down to $60-\mathrm{cm}$ exceeded $200 \mathrm{~kg}$ $\mathrm{ha}^{-1}$ under heavy and approached $100 \mathrm{~kg}$ $\mathrm{ha}^{-1}$ under light grazing. Grazing intensities such as the heavy treatment are a potential risk to the environment as a result of leaching and denitrification, although this was not verified within the study. Amounts of mineral-N under medium and light grazing intensities are of less environmental concern, but were greater than those found under other cropping systems from nearly identical soils found in the region. Amounts of residual mineral-N found under these more normal grazing intensities indicate further research is necessary to improve $\mathrm{N}$ use efficiency under intensive grazing on the prairie parkland and that economic efficiencies may be gained through reduced fertilizer-N application. Phosphorus levels in the soil surface $(0-15 \mathrm{~cm})$ were not high enough to be of environmental concern, but economically, annual additions of P-fertilizer would not be practical.

\section{References}

Ashworth, J. and K. Mrazek. 1995. 'Modified Kelowna" test for available phosphorus and potassium in soil. Commun. Soil Sci. Plant Anal. 26:731-739.

Baron, V.S., E. Mapfumo, M.A. Naeth, and D.S. Chanasyk. 1999. Sustainable grazing systems for perennial and annual forages on sloped lands. Canada-Alberta Environmentally Sustainable Agr. Agreement Final Rep. RES-024-93, 161pp.

Baron, V.S., H.G. Nadja, D.F. Salmon, J.R. Pearen, and A.C. Dick. 1993. Cropping systems for spring and winter cereals under simulated pasture: yield and yield distribution. Can. J. Plant Sci. 73:703-712.
Bransby, D.I., A.G. Matches, and G.F. Krause. 1977. Disk meter for rapid estimation of herbage yield in grazing trials. Agron. J. 69:393-396.

Briske, D.D. and R.K. Heitschmidt. 1991. An ecological perspective, pp 7-28. In: Grazing Management: an Ecological Perspective. Eds. R.K. Heitschmidt and J.W. Stuth. Timber press, Portland, Ore.

Campbell, C.A., R.P. Zentner, H.H. Janzen, and K.E. Bowren. 1990. Crop rotation studies on the Canadian prairies. Research Branch, Agriculture Canada. Pub. No. 1841/E 133 p.

Doran, W.J., G.H. Bowman, and D.R. Walker. 1963. The productivity of fertilized pastures in central Alberta. Can. J. Plant Sci. 43:188-194.

Elliot, C.R., C.H. Anderson, and B.D. Owen. 1961. Studies with fertilized pastures on a heavy textured soil in Northern Alberta. Can. J. Plant Sci. 41:261-267.

Entz, M. H., W.J. Bullied, and F. KatepaMupondwa. 1995. Rotational benefits of forage crops in Canadian Prairie cropping systems. J. Prod. Agr. 8:521-529.

Ewanek, J. 1995. Survey of nitrate-nitrogen in the soil profile under different field management practices in Manitoba. In: Agriculture impacts on water quality. Proc. of a Western Canada Symp. Red Deer, Alberta, Feb. 21-22, 1995.

Ferguson, W.S. and B.J. Gorby. 1971. Effect of various periods of seed down to alfalfa and bromegrass on soil nitrogen. Can. J. Soil. Sci. 51:65-73.

Haynes, R.J. and P.H. Williams. 1993. Nutrient cycling and soil fertility in the grazed pasture ecosystem. Adv. in Agron. 49:119-199.

Hoyt, P.B. and R.H. Leitch. 1983. Effects of forage legume species on soil moisture, nitrogen and yield of succeeding barley crops. Can. J. Soil Sci. 63:125-136.

Johnson, J. and D. Eckert 1995. Best management practices: land application of animal manure. The Ohio State University Extension Agronomy facts. AGF - 208-95, 1995. $10 \mathrm{pp}$.

Kopp, J.C., W.P. McCaughey, and K.M. Wittenburg. 1997. Cow-calf production response to pasture forage species. XVIII Int. Grassl. Congress 29:37-38.

Malhi, S.S. and M. Nyborg. 1986. Increase in mineral $\mathrm{N}$ in soils during winter and loss of mineral $\mathrm{N}$ during early spring in North-central Alberta. Can. J. Soil Sci. 66:397-409.

Mapfumo, E., D.S. Chansyk, M.A. Naeth, and V.S. Baron. 2000. Grazing impacts on selected soil parameters under short term forage sequences. J. Range. Manage. 53:466-470.

Mathews, B.W., L.E. Sollenberger, and J.P.Tritschler II. 1996. Grazing systems and spatial distribution of nutrients in pastures Soil considerations. pp 213-229. In: Nutrient Cycling in Forage Systems. Proc. Sym. March 7-8, 1996 Columbia, Mo. Eds. R.E. Joost and C.A. Roberts. Potash and Phosphate Institute. and the Foundation for Agron. Res., Manhattan, Kan. 
Nuttall, W.F., D.A. Cooke, J. Waddington, and J.A. Robertson. 1980. Effect of nitrogen and phosphorus fertilizers on a bromegrass and alfalfa mixture grown under two systems of pasture management. I. Yield, percentage legume in sward, and soil tests. Agron J. 72:289-298.

Roquette, F.M. Jr., J.E. Matocha, and R.L. Duble. 1973. Recycling and recovery of nitrogen, phosphorus and potassium by coastal bermudagrass. II. Under grazing conditions with two stocking rates. J. Environ. Qual., 2:129-132.

SAS Institute 1989 SAS/STAT user's guide Version $6,4^{\text {th }}$ Edition. SAS Institute, Cary, N.C.

Steel, R.G.D. and J.H. Torrie. 1980. Principles and Procedure of Statistics. A Biometrical Approach. $2^{\text {nd }}$ Ed. McGraw-Hill Book Company, New York, N.Y. 633p.
Stout, W.L., S.A. Fales, L.D. Muller, R.R. Schnabel, W.E. Priddy, and G.F. Elwinger. 1997. Nitrate leaching from cattle urine and faeces in Northeast USA. Soil Sci. Soc. Amer. J. 61:1787-1794.

Twerdoff, D.A., D.S. Chanasyk, E. Mapfumo, M.A. Naeth, and V.S. Baron. 1999. Soil water regimes under rotational grazing of annual and perennial forages. Can. J. Soil Sci.79: 627-637.

Wedin, D.A. 1996. Nutrient cycling in grasslands: An ecologists perspective. pp 29-44. In: Nutrient Cycling in Forage Systems. Proc. Sym. March 7-8, 1996 Columbia, MO. Eds. R.E. Joost and C.A. Roberts. Potash and Phosphate Institute and the Foundation for Agron. Res., Manhattan, Kan.
Wedin, D.A. and D. Tilman. 1990. Species effects on nitrogen cycling: a test with perennial grasses. Oecologia 84:433-441.

Whitehead, D.C. 1995. Amounts, sources and fractionation of organic nitrogen in soils. pp. 82-107. In: Grassland nitrogen. Ed. D.C. Whitehead. CAB International, Wallingford, Oxon, U.K.

Woodmansee, R.G., I. Vallis, and J.J. Mott. 1981. Grassland nitrogen. F.E. Clark and T. Rosswall (eds). Terrestrial Nitrogen Cycles. Ecol. Bull. (Stockholm) 33:443-462.

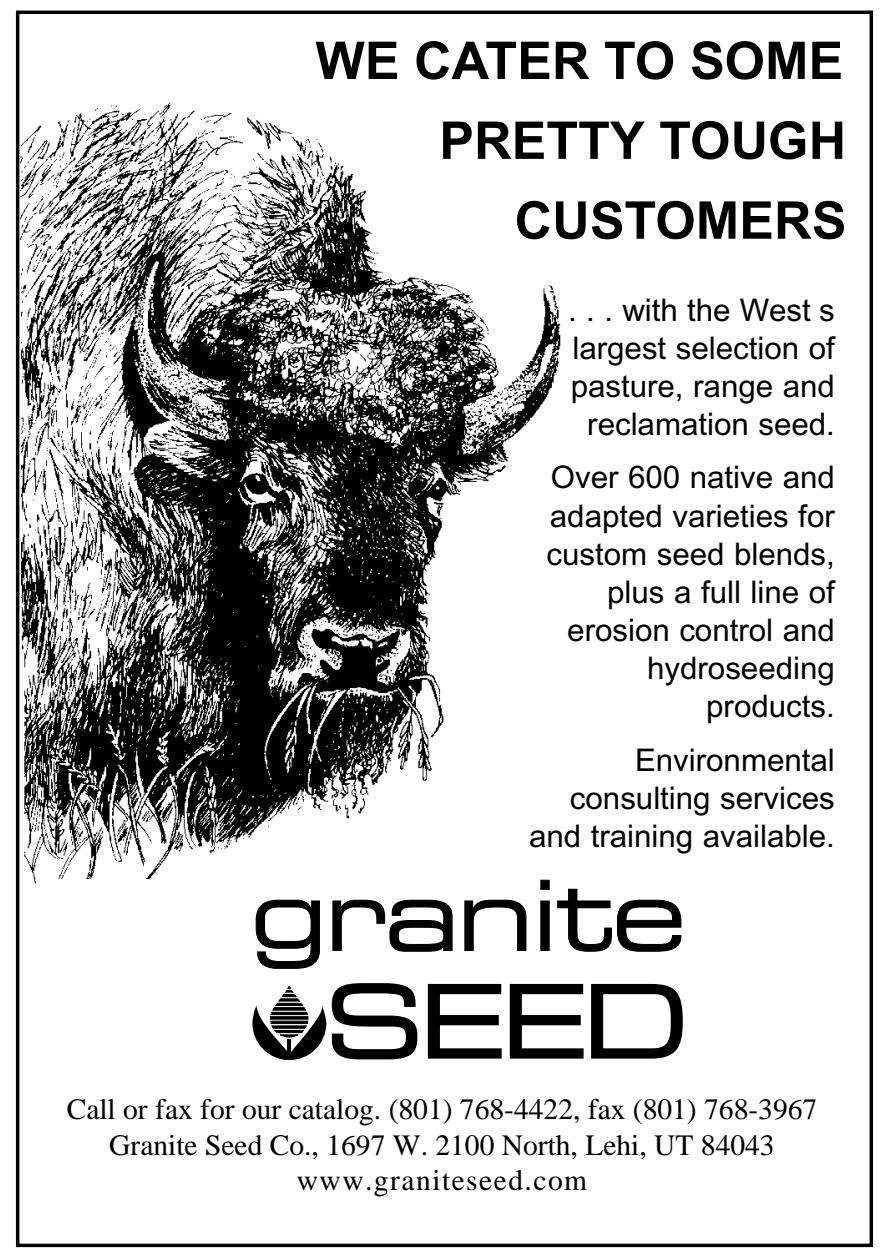

